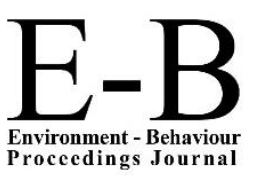

\title{
AicE-Bs2015Barcelona
}

$6^{\text {th }}$ Asia-Pacific International Conference on Environment-Behaviour Studies,

Barcelona School of Architecture (ETSAB), Barcelona, Spain,31 Aug.- 05 Sep. 2015

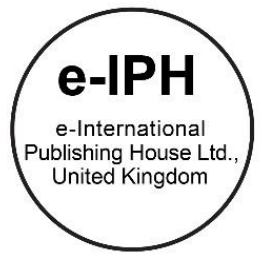

\section{Environmental Protection and Value Creation}

\author{
Faizah Darus ${ }^{1 *}$, Wan Mashitah Yusof ${ }^{2}$, Tamoi Janggu ${ }^{3}$ \\ ${ }^{1}$ Accounting Research Instutute (ARI),Faculty of Accountancy, Universiti Teknologi MARA, Shah Alam, Malaysia \\ ${ }^{2}$ Commerce Department, Polytechnic Port Dickson Malaysia \\ ${ }^{3}$ Faculty of Accountancy, Universiti Teknologi MARA, Shah Alam Malaysia
}

\begin{abstract}
The managers of corporations can play a significant role to protect the natural environment. This study aims to examine the environmental disclosure of 200 Shariah compliant companies for 2013 and the subsequent effect of such disclosure for the organizations. The results of content analyses of the annual reports revealed that managers from the Plantation industry disclosed more environmental information. The regression analysis revealed a significant relationship between environmental information provided and the subsequent value created for the organizations. The findings of the study can help managers to position better their environmental strategy to enhance the overall value of their organizations.

(C) 2016. The Authors. Published for AMER ABRA by e-International Publishing House, Ltd., UK. Peer-review under responsibility of AMER (Association of Malaysian Environment-Behaviour Researchers), ABRA (Association of Behavioural Researchers on Asians) and cE-Bs (Centre for Environment-Behaviour Studies, Faculty of Architecture, Planning \& Surveying, Universiti Teknologi MARA, Malaysia.
\end{abstract}

Keywords: Environment; Shariah compliance companies; sustainability; corporate social responsibility

\section{Introduction}

The negative impacts on the natural environment due to various economic activities are becoming an increasing concern among stakeholders and the public at large. From a business perspective, protection of the natural environment is concerned with the organizations' impacts on living and non-living natural systems, including ecosystems, land, air, and water (Yusoff, Darus, Fauzi \& Purwanto, 2013). According to Gunggut, Abg Mohd Saufi, Zaaba, Mei Liu, (2014), the loss of forest is worrying since the forest is important not only for environmental and economic reasons, but also social and cultural reasons. Stakeholders of corporations are becoming more appreciative of companies that disclose their corporate social responsibility (CSR) information in their annual and sustainability reports and are attaching a higher value to these types of organizations (Othman, Darus \& Arshad, 2011). Therefore, managers of corporations need to ensure that the environmental strategies of their companies are consistent with the overall corporate strategies and are embedded as part of the overall governance mechanisms to ensure that such strategies will add value to the organizations. In this context, Islamic-based organizations such as Shariah

${ }^{*}$ Corresponding author. Tel.:+60193350388; fax:+60355444992.

E-mail address: faiza634@salam.uitm.edu.my. 
compliant companies in Malaysia, by virtue of the Islamic status granted to them by the Securities Commission of Malaysia are expected to uphold the Islamic accountability of ensuring that they are accountable for meeting their socio-economic objectives consistent with Shariah laws and obligations.

The aim of this study is to provide evidence on the environmental practices of Shariah compliant companies (SHCCs) and the subsequent impact of such practices in creating value for the organizations. The findings from this study would provide insights on the current state of environmental practices of SHCCs benchmarked against an Islamic-Environmental Index. Content analyses of the annual and sustainability reports of 200 SHCCs from four (4) industries namely; Construction, Plantation, Consumer Products and Industrial Products were carried out to evaluate the quality of information disclosed by management of these companies relating to their environmental practices for the year 2013. Even though many attempts have been made by prior literature to explain factors underlying the reasons for companies to disclose their environmental information (Liu \& Anbumozhi, 2009; Yusoff, Darus, \& Rahman, 2015) but few studies have examined the environmental practices of Islamic-based organizations and the subsequent impact of such practices in creating value for the organizations.

This paper is organized into four sections. The subsequent section proceeds with the literature review of the study. The third section provides the methodology, and this is followed by the results and discussion section. The final section offers the conclusion and implications of the results.

\section{Literature Review and Hypothesis Development}

\subsection{Accountability of Islamic-based organizations}

Of late, there has been an increasing demand and awareness among Muslim communities globally for investments in financial assets to be aligned with the precepts of Islamic teachings (Hassan \& Harahap, 2010). Malaysia is one of the Muslim countries which is in the forefront of addressing this flourishing needs of the Muslim community by establishing SHCCs who will invest in Shariah-compliant securities. As of 25 May 2013 which is the year of the study, 825 companies listed on Bursa Malaysia were classified as SHCCs that represented $89 \%$ of the total number of companies listed on Bursa Malaysia. This indicates the importance of this type of companies where the amount of capital invested is now dominating the majority of the overall capital market. The Shariah Advisory Council (SAC) which was established by Securities Commission (SC) is responsible to approve the core activities of SHCCs to ensure that they are not contrary to Shariah principles.

Therefore, as Islamic-based organizations, SHCCs ultimate accountability is to God where managers as trustees are expected to take care of the natural environment entrusted to them (Hassan \& Harahap, 2010; Maali, Casson \& Napier, 2006). Therefore, for the stakeholders to evaluate the accountability of SHCCs, it is important that information about their economic and social accountability be disclosed. According to Baydoun \& Willet, (2000) the disclosure of information from an Islamic perspective should fulfill two general requirements: full disclosure and social accountability.

\subsection{Environmental information and value creation}

The involvement of SHCCs in activities of environmental protection and preservation of the eco-system should be communicated by the managers to their stakeholders to enable such activities to create value for the organizations. Environmental communication can range from communication to decision-making process and procedure to media publicity and ultimately to public attention (Bakar 2015). This is because the environmental information provides good indicators to stakeholders of management commitment towards preserving and protecting the natural environment and its willingness to engage in the environmental protection and improvement activities (Perry \& Teng, 1999). Historically, the disclosure of environmental information worldwide began in the late 1980s and the 1990s as a response to investors' concerns about the environment resulting in companies voluntarily disclosing the impact of their activities (O'Dwyer, 2001). However, a review of prior literature suggests that the quality of such environmental information provided to date can be further improved as the information provided was still very little, of general and qualitative type information aimed at creating a positive corporate image (Nik Ahmad \& Sulaiman, 2004; Yusoff \& Darus 2012).

The environmental initiatives undertaken by management are expected to bring benefits to the organisations (Husted \& Allen, 2007; Mohd. Yusof. Abdul Manan, Abd. Karim \& Mohd. Kassim 2015; Othman, Darus and Arshad, 2011; Braga Junior et al. 2014; Othman, Arshad, Abdul Aris and Mohd Arif, 2015). Braga Junior et al. (2014) pointed out that environmental concern has a 
significant relationship with the intention of purchase by consumers. Husted and Allen (2007) argued that firms that focus and are concerned with CSR projects will create value for the firm when the activities conducted, are highly visible to the public. Similarly, Scharf, Fernandes and Korman (2012) pointed out that by engaging in CSR activities firms will be able to strengthen the brand of their products among the stakeholders which in turn will improve brand ranking. The value created for a firm by engaging in CSR practices can be either tangible or intangible (Low, 2000; Gholami, 2011). In this study it is expected that when managers of SHCCs provide more environmental information to stakeholders, such actions will be able to create value for the organizations especially if the environmental activities are performed in line with the principles of Shariah. Hence, the following hypothesis is developed; $\mathrm{H} 1$ : There is a significant positive relationship between environmental information and value creation.

\section{Methodology}

\subsection{Environmental information}

A content analysis approach was used to gather the environmental information disclosed from the annual and sustainability reports of 200 SHCCs for the year 2013. This method allows the accountability of the SHCCs about their environmental practices to be evaluated through the disclosure of information to the public. An Islamic CSR-Environment index developed by Yusoff \& Darus (2014) was used as a tool to measure the environmental information disclosed based on five (5) key areas: Environmental related policy, Climate change mitigation and adaptation, Prevention of pollution, Green products and services, Protection and restoration of the natural environment

Table 1 below presents the list of possible environmental information based on the five (5) key areas. A total of twenty-one (21) environmental items comprising of six (6) vital items and fifteen (15) recommended items (15) were used to measure the environmental disclosure made by the SHCCs. The vital environmental items represented essential activities that should be prioritized by the SHCCs to be undertaken while the recommended items relate to optional/suggested activities ('good to have') that could be undertaken by the SHCCs. The environmental items were then ranked based on the degree of specificity of each environmental item. Four (4) data rating scales were used to measure the related level of extensiveness of the environmental disclosure; namely, a score of 1 for general information, 2 for qualitative information, 3 for quantitative information and 4 for a combination of qualitative and quantitative information.

Table 1. No. of possible items according to key aspects of environment

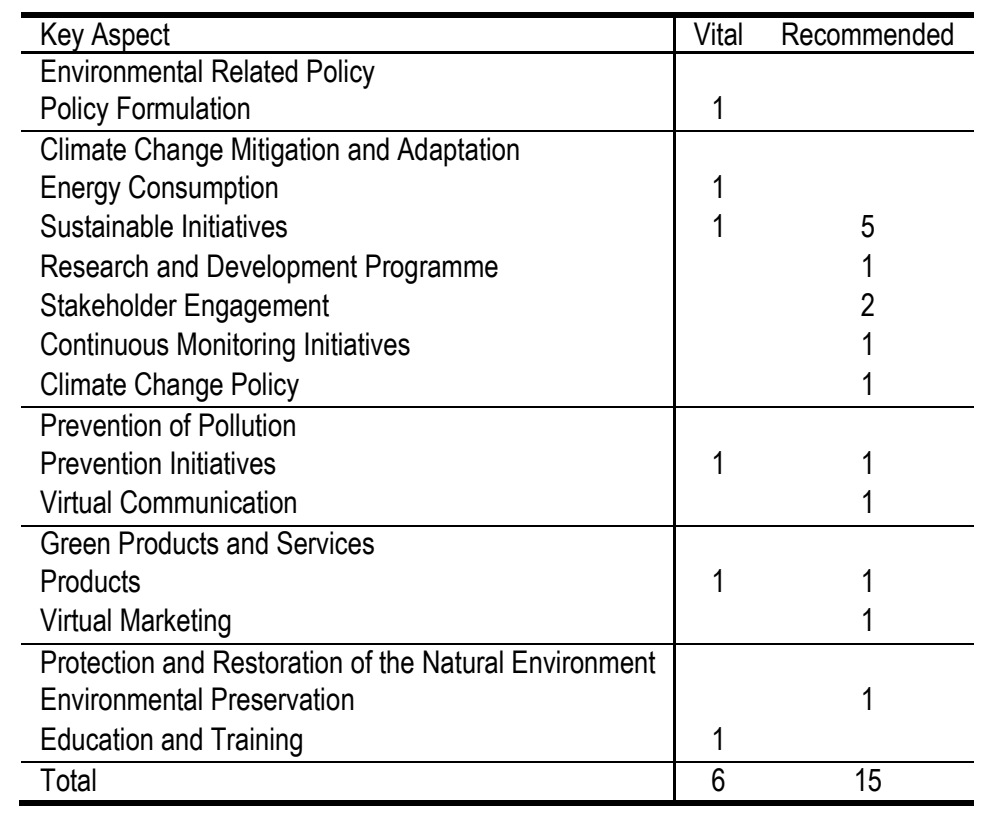




\subsection{Value creation}

The value creation to the organization as a result of disclosure of environmental information was measured both in terms of financial and non-financial attributes to form a Value Creation Index. Laitenin (2004) suggested that profitability is one of the determinant factors of value creation. In addition, Low (2000) and Kalafut \& Low (2001), argues that value creation of a firm can be determined by other non-financial attributes such as innovation, quality, customer relations, management capabilities, alliances, technology, brand value, employee relations and environment and community issues. Return on assets (ROA) was used to measure the financial attributes in this study (Abdulle \& Kassim, 2012) while the non-financial attributes were measured by using two (2) measures namely; innovation and brand value. Table 2 presents the Value Creation Index developed for the purpose of this study.

Table 2. Value creation index

\begin{tabular}{ccll}
\hline No & Attribute & \multicolumn{1}{c}{ Measurement } & \multicolumn{1}{c}{ Score } \\
\hline 1 & Profitability & ROA against ROA for all sample & $\begin{array}{l}\text { Value '1' if ROA above average ROA for all } \\
\text { sample and '0' if otherwise }\end{array}$ \\
\hline 2 & Innovation & $\begin{array}{l}\text { Evidence on introduction of new } \\
\text { product to market }\end{array}$ & $\begin{array}{l}\text { Value '1' if there is a new product and '0' if } \\
\text { otherwise }\end{array}$ \\
\hline 3 & Brand Value & Brand Award (Local) & $\begin{array}{l}\text { Value '1' if received local brand awards and } \\
\text { '0' if otherwise } \\
\text { Value '1' if received international brand } \\
\text { awards and '0' if otherwise }\end{array}$ \\
& Brand Award (International) & 4 \\
\hline
\end{tabular}

The relationship between the environmental information provided and value creation was analysed using the following regression model to test $\mathrm{H} 1$.

$$
E N V I=\beta 0+\beta 1 V C+\varepsilon t
$$

where ENVI is the quality of environmental information, $\mathrm{VC}$, is value creation and $\varepsilon$ is an error term

\section{Results and Discussion}

\subsection{Descriptive analysis}

Fig. 1. below presents the level of environmental information provided based on industry while Figure 2 presents the mean score of environmental information based on Key Areas for the sample industry. The findings from Figure 1 revealed that the Plantation industry discloses the highest level of environmental information followed by the Industrial Products, Consumer Products, and Construction industry. The low disclosure for the Construction industry is a concern because Construction industry by its nature is closely linked with activities of deforestation, waste generation and disposal where such activities put enormous stress on the environment.

The results from Fig. 2. revealed that the Plantation industry had the highest mean score for the disclosure of environmental information for Key Area 1: Environmental Related Policy, Key Area 2: Climate Change Mitigation and Adaptation and for Key Area 4: Green Products and Services. The higher disclosure of information for the Plantation industry could be due to an increased awareness about the impact of uncontrolled economic development on the environment, especially where the majority of the companies in the Plantation industry in Malaysia are certified members of the Malaysian Palm Oil Board (MPOB) where they are required to disclose information to comply with MPOB's code of practices for quality, food safety, and sustainability. The Industrial Products industry had the highest mean score for Key Area 3: Prevention and Pollution. The higher score for Key Area 3 for the Industrial Product sector could be because companies in this industry comprise of manufacturing, mining, and utility companies that are closely linked to manufacturing activities and are therefore more exposed to pollution. Thus, the companies seemed to be taking the initiatives to prevent pollution at the source by engaging in pollution prevention activities. For Key Area 
5: Protection and Restoration of the Natural Environment, the Construction industry is at the forefront in terms of provision of information relating to this key area. The focus of the Construction Industry on Key Area 5 could be due to the nature of the industry where more activities involving the protection and the restoration of the natural environment need to be done due to their construction activities. The higher disclosure made by the Plantation, Industrial Product and Construction industries are consistent with arguments by prior literature where firms that operate in industries that are perceived to be environmentally sensitive seemed to be more likely to provide positive environmental information in their annual reports to differentiate themselves from the worst polluters (Bewley and Li, 2000).

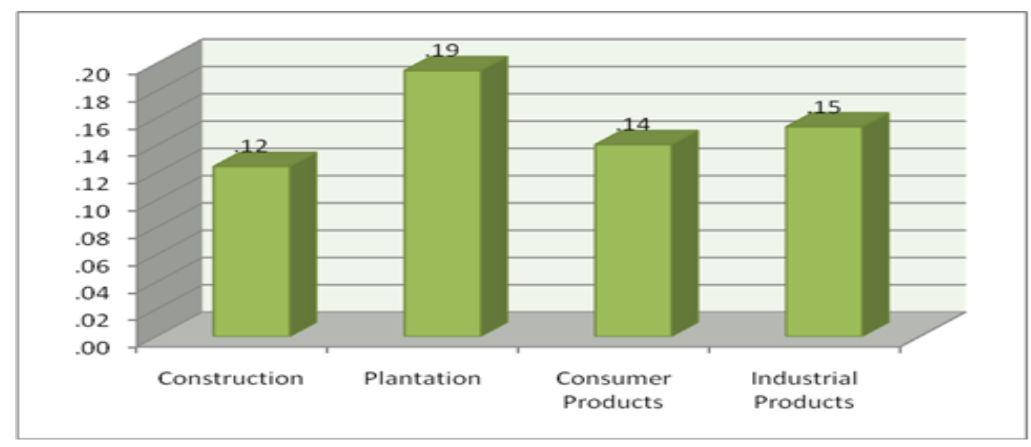

Fig 1. Level of environmental disclosure by industry

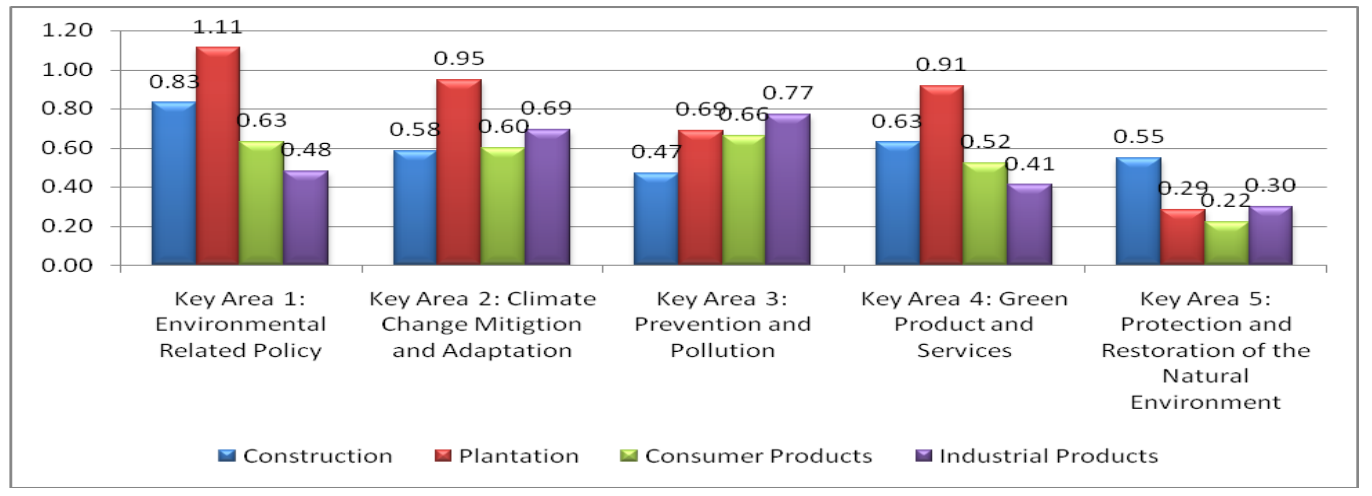

Fig. 2. Mean score of environmental disclosure by key area based on industry

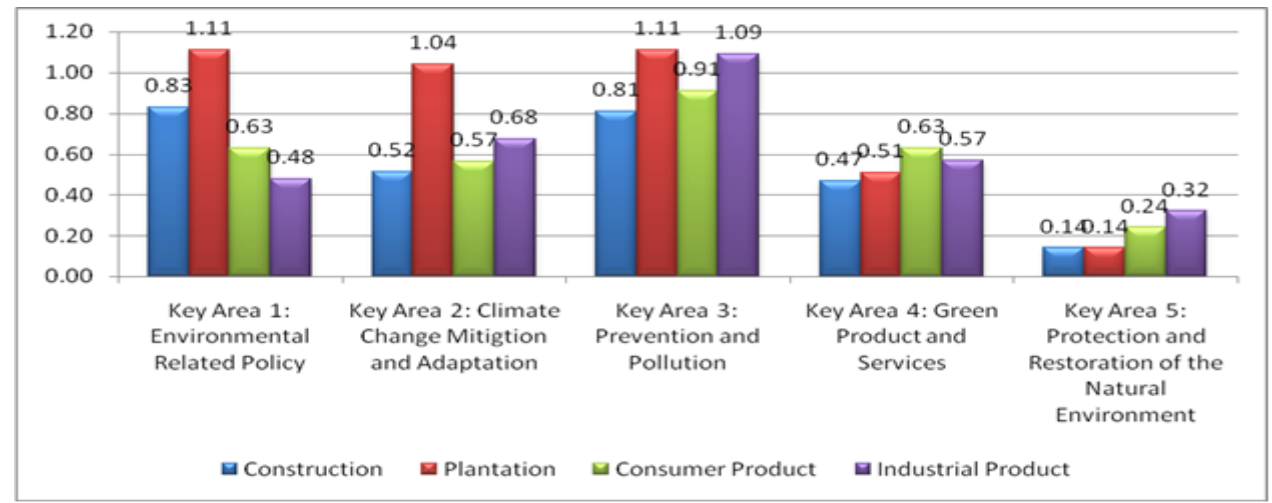

Fig. 3. Mean score of vital disclosure by industry 
Fig. 3. above presents a subsequent analysis of the items categorized into vital environmental items while Fig. 4. presents the results of the recommended environmental items by industries. The results from Figure 3 indicates that the management of the Plantation industry disclosed more information regarding items that are considered as vital information based on the IslamicEnvironment index. The highest information disclosed relates to Key Area 1: Environmental Related Policy and Key Area 3: Prevention and Pollution followed by Key Area 2: Climate Change Mitigation and Adaptation. The results from Figure 4 present the mean score of the recommended items by industry. The results revealed that again the Plantation industry had the highest mean score for Key Area 2: Climate Change Mitigation and Adaptation and for Key Area 5: Protection and Restoration of the Natural Environment. The results suggest that the management of the Plantation industry of the SHCCs is in the forefront in the context of providing information about their involvement with the natural environment both for the vital and the recommended items.

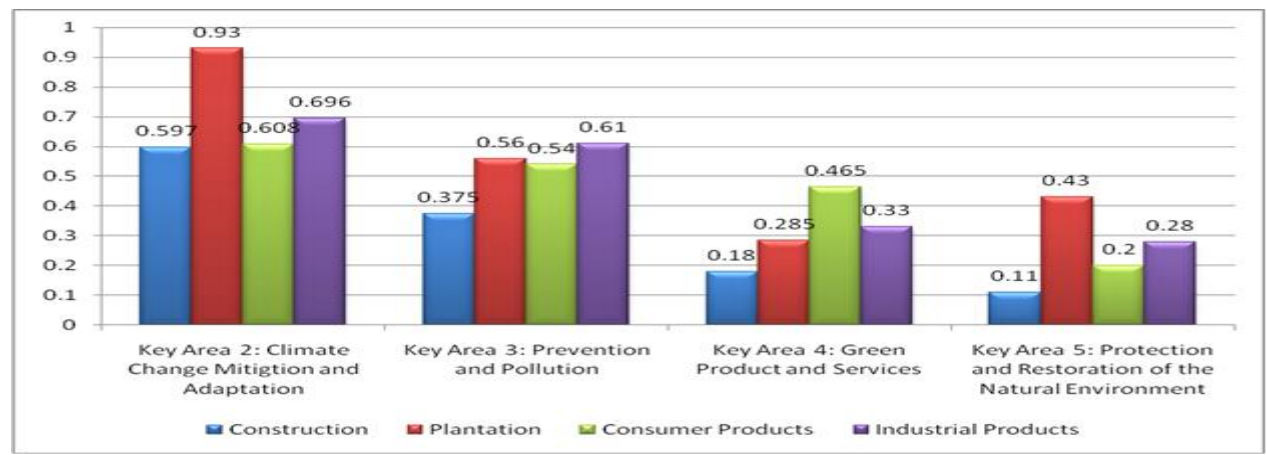

Fig. 4. Mean score of recommended disclosure by industry

Table 3 presents the descriptive statistics for the Value Creation Index. The highest mean score relates to the profitability attributes (0.52). The lowest mean score (0.04) was for Brand Award (International).

Table 3. Descriptive statistics of value creation index

\begin{tabular}{cccccc}
\hline Attributes & $\mathrm{N}$ & Min & Max & Mean & Std Deviation \\
\hline Value Creation & 200 & 0 & 4 & 0.88 & 0.918 \\
\hline Profitability & 200 & 0 & 1 & 0.52 & 0.501 \\
\hline Innovation & 200 & 0 & 1 & 0.19 & 0.389 \\
\hline Brand Award (local) & 200 & 0 & 1 & 0.13 & 0.337 \\
\hline Brand Award (International & 200 & 0 & 1 & 0.04 & 0.196 \\
\hline
\end{tabular}

\subsection{Regression analysis}

Table 2 presents the result of the regression analysis between ENVDISC and VC. The F-statistic for the model is 32.816 and is significant, and the adjusted R2 is 0.138 and significant with $p<.01$. This indicates that $13.8 \%$ of the variance in the value creation can be explained by environmental disclosure. The results also revealed that Environmental Disclosure $(p<.01)$ is significant to value creation.

$\mathrm{H} 1$ predicts that there is a significant positive relationship between environmental information and value creation. Therefore, $\mathrm{H} 1$ is accepted. Therefore, it is expected that the disclosure of environmental information by SHCCs will result in value creation for the organizations. This suggests that the higher the quality of environmental disclosure made by SHCCs the higher the value created by the companies. This is consistent with Hussainey \& Salama (2010), who pointed out that stakeholders are now more interested in environmental issues and disclosures rather than just focusing on the quality of reported earnings. Also, from an Islamic perspective the full disclosure of information, both from the economic and social responsibility perspective will meet the Islamic accountability (Baydoun and Willet, 2000). 
Table 4. Simple regression results for environmental disclosure and value creation

\begin{tabular}{|c|c|c|c|c|c|c|}
\hline \multicolumn{7}{|c|}{ Dependent Variables: VC (Value Creation) } \\
\hline \multicolumn{7}{|c|}{ R Square $=0.142$, Adjusted $R$ Square $=0.138, F=32.816$, Sig. $=0.000$} \\
\hline & \multirow[b]{2}{*}{ B } & \multirow[b]{2}{*}{ Beta } & \multirow[b]{2}{*}{$t$} & \multirow[b]{2}{*}{ Sig. } & \multicolumn{2}{|c|}{ Collinearity Statistics } \\
\hline & & & & & Tolerance & VIF \\
\hline (Constant) & .556 & & 6.783 & .000 & & \\
\hline $\begin{array}{l}\text { Environmental } \\
\text { Information }\end{array}$ & 2.094 & .377 & 5.729 & $.000^{* *}$ & 1.000 & 1.000 \\
\hline
\end{tabular}

**Significant at $1 \%$ level

\section{Conclusion}

It is important that managers of business organizations be concerned and ensure that their business operations that involve the process of taking inputs from capitals and converting them into outputs be incongruent with the ethical values and aspiration of their original existence. Islamic-based organizations such as Shariah compliant companies in Malaysia, by virtue of the Islamic status are expected to uphold the Islamic accountability not only towards the products and services that are being offered but to also meet the social objective in accordance with Shariah. The aim of this study is to evaluate the environmental practices of Shariah compliant companies through the lens of an Islamic-Environmental Index and the subsequent impact of such practices in creating value for the organizations. Content analyses of the annual and sustainability reports of 200 SHCCs for the year 2013 from four (4) industries were undertaken to gather the environmental information provided by the management of these companies. The results from the study revealed that companies in the Plantation industry were the leaders in the provision of environmental information and were the most successful in terms of prioritization of such practices in accordance with the values and principles of Shariah. However, the quality of information disclosed by all the SHCCs could be further improved to include measurable quantitative information where the outputs and outcomes as a result of such activities could be easily assessed by the stakeholders. This is especially critical as the results of the study revealed that the quality of environmental disclosure provided can create value to the organizations. Such value creation could enhance the competitiveness and performance of the SHCCs and in turn will fulfill the Malaysian government commitment to making Malaysia as the global leader in Islamic capital market.

\section{Acknowledgements}

The authors would like to express their gratitude to the Ministry of Education for funding this research under the FRGS grant and the Accounting Research Institute, Universiti Teknologi MARA for facilitating this research project

\section{References}

Abdulle, M.Y. \& Kassim, S.H. (2012). Impact of global financial rrisis on the performance of Islamic and conventional banks: Empirical evidence from Malaysia. Journal of Islamic Economics, Banking and Finance, Vol. 8 (No. 4), pp. 9-20.

Bakar, D.A. (2015) Good, the Bad and the Ugly: Framing the country development through environmental communication, Procedia - Social and Behavioral Sciences $168(2015,8-12$

Baydoun, N., \& R. Willet. (2000). Islamic corporate reports. Abacus, Vol. 36 No. 1, pp. 71-90.

Bewley K, Li Y. 2000. Disclosure on environmental information by Canadian manufacturing companies: A voluntary disclosure perspective.Advances in International Accounting and Management 1: 201-226.

Braga Junior, S.S, Silva, D., Gabriel, MLD.S and Braga, WRO (2015), The effects of environmental concern on purchase of green products in retail, Procedia Social and Behavioral Sciences 170 (2015) 99 - 108.

Gholami, S. (2011). Value Creation Model through Corporate Social Responsibility (CSR). International Journal of Business and Management, Vol. 6(No. 9), pp. 148-154. 
Gunggut, H , Ag Mohd Saufi, D. Zaaba, Z.,Mei Liu, MS (2014) Where have all the Forests Gone? Deforestation in land below the wind, Procedia - Social and Behavioral Sciences 153 ( 2014 ) 363 - 369

Hassan, A. \& Harahap, S.S. 2010. Exploring corporate social responsibility disclosure: the case of Islamic Banks. International Journal of Islamic and Middle Eastern Finance and Management 3(3): 203-227.

Hussainey, K. and Salama, A. (2, 010). The importance of corporate environmental reputation to investors. Journal of Applied Accounting Research, Vol. 11 ( Iss. 3), pp. $229-241$.

Husted, B. W. and Allen, D. B. (2007). Strategic Corporate Social Responsibility and Value Creation among Large Firms: Lessons from the Spanish Experience. Long Range Planning, Vol. 40, 594-610.

Kalafut, P. C. \& Low, J. (2001). The value creation index: quantifying intangible value. Strategy \& Leadership, Vol. 29 (Iss 5), pp. 9 - 15.

Laitinen, E. K. (2004). Nonfinancial Factors as Predictors of Value Creation: Finnish Evidence. Review of Accounting and Finance, Vol. 3 (Iss. 3 ), pp. 84 - 130.

Liu, X. and Anbumozhi, V. (2009). Determinant factors of corporate environmental information disclosure: an empirical study of Chinese listed companies. Journal of Cleaner Production, 17, 693-700.

Low, J. (2000). The value creation index. Journal of Intellectual Capital, Vol. 1( Iss. 3), pp. 252 - 262.

Maali, B., Casson, P., \& Napier, C. (2006). Social reporting by Islamic banks. Abacus, 42(2), pp. 266-289.

Mohd Yusof J., Abdul Manan H., Abd Karim N., and Mohd. Kassim N.A., (2015) Customer's Loyalty effects of CSR Initiatives, Procedia - Social and Behavioral Sciences 170 (2015) $109-119$

Nik Ahmad, N.N. and Sulaiman, M. (2004). Environment disclosure in Malaysia annual reports: A legitimacy theory perspective. International Journal of Commerce and Management, Vol. 14 Iss 1, pp. 44 - 58.

O'Dwyer B.( 2001) The state of corporate environmental reporting in Ireland. ACCA research report No. 69, ACCA: London, 48 pp.

Othman, R., Arshad, R., Abdul Aris, N., and Mohd Arif, S.M. (2015) Organizational Resources and Sustained Competitive Advantage of Cooperative Organizations in Malaysia, Procedia - Social and Behavioral Sciences 170 ( 2015 ) 120 - 127

Othman, S., Darus, F. \& Arshad, R. (2011). The influence of coercive isomorphism on corporate social responsibility reporting and reputation. Social Responsibility Journal, Vol. 7(Iss 1), pp. 119 - 135.

Perry, M., \& Teng T.S., (1999) "An overview of trends related to environmental reporting in Singapore", Environmental Management and Health, Vol. 10 Iss: 5 , pp.310 - 320

Scharf, E. R., Fernandes, J., Kormann, B.D., (2012) "Corporate social responsibility to build strong Brazilian bank brand", International Journal of Bank Marketing, Vol. 30 Iss: 6, pp.436-451

Yusoff, H. \& Darus, F. (2012). Environmental Reporting Practices in Malaysia: Is it a Mechanism for Corporate Accountability and Stakeholder Engagement? Malaysian Accounting Review, Special Issue, Vol. 11, No.2, pp. 137-159.

Yusoff, H., Darus, F., Fauzi H. and Purwanto, Y. (2013), Exploring the Environmental Reporting Practices of Islamic Banks: A Case of Malaysia and Indonesia, Journal of Energy Technologies and Policy, 3, 11, 440-445, Special Issue for ICEESE 2013

Yusoff, H., Darus, F., (2014), Mitigation of Climate Change and Prevention of Pollution Activities: Environmental Disclosure Practice in Islamic Financial Institutions, Procedia - Social and Behavioral Sciences, 145 (2014) 195-203,

Yusoff, H., Darus, F. and Rahman, S.A.A. (2015) 'Do corporate governance mechanisms influence environmental reporting practices? Evidence from an emerging country', International Journal. Business Governance and Ethics, 10, (1) 76-96. 